OPINION PIECE

\title{
Equity and Students as Partners: The Importance of Inclusive Relationships
}

Sarah O'Shea, School of Education, University of Wollongong, Australia

Contact: saraho@uow.edu.au

\section{INTRODUCTION}

Higher education (HE) institutions invite and encourage students from a diversity of backgrounds to participate in further learning, yet expect individuals to both fund this endeavour and conform to institutional expectations of the successful learner (O'Shea \& Delahunty, 2018). This presents an uncomfortable contradiction about inclusion in HE. Universities are accepting an increasingly diverse student population (Marginson, 2016), but, simultaneously, an increasingly neoliberal agenda shaping $\mathrm{HE}$ is driving competition and rewarding individualism with social inclusion practices within university often being diminished (for more on neoliberalism in relation to students-as-partners see Matthews, Dwyer, Hine, \& Turner, 2018).

In this opinion piece, I argue that a student partnership approach creates trust filled partnerships between staff and equity-seeking students. Forging these genuine and collaborative partnerships within the equity and outreach space offers potential to both envision and create a university for all, rather than for just some. I draw on my own experiences, practices, and research while contributing to the ongoing discourse in the emerging students-as-partners community.

\section{EXPLORING EQUITY IN THE CONTEXT OF STUDENTS-AS-PARTNERS}

Translating existing capitals into those expected and required within university can be difficult in an individualised system, but if we shift the relational aspects of $\mathrm{HE}$ to better reflect an environment characterised by collaboration and partnership, this translation becomes more achievable. As Matthews, Dwyer, Hine, and Turner (2018, p. 1) assert, "students as partners is fundamentally about meaningful relationships between students and staff members," which positions partnerships as a potentially powerful framework within the student equity space. If we engage students through partnerships that explicitly value mutual respect, reciprocity, and shared responsibility for all aspects of teaching and learning, we ultimately challenge traditional and taken-for-granted assumptions. This is beautifully articulated by Ntem (2017), who states:

Students as Partners ( $\mathrm{SaP}$ ) is fundamentally about meaningful relationships between students and staff members at a university. 
Too many times, assumptions are made and protected, such as about who has knowledge about teaching and learning... Students as Partners, however, challenges those dynamics and provides insight into what faculty may not always realize. (cited in Cliffe et al, 2017, p. 3)

Ideally such mutuality should underpin all efforts to support and engage our increasingly diverse student population. Such recognition would add value to the knowledge these learners bring to $\mathrm{HE}$ and assist in forging more cooperative and meaningful learning communities within HE (Matthews, Cook-Sather, \& Healey, 2018).

Students-as-partners approaches to co-design and co-create offer a reciprocal process through which all participants have the opportunity to contribute equally to a learning environment, although not necessarily in the same ways (Cook-Sather, Bovill, \& Felten, 2014). This is important when we consider students from diverse backgrounds because too often outreach and interventions designed to support these cohorts are developed by staff who may have limited understanding of the complex realities that these students may exist within. Wellmeaning interventions may slide unintentionally towards deficit perspectives that regard these students as lacking (knowledge, wealth, cultural capitals) and in need of aspiration raising. This perspective then fails to situate activities within learners' actual realities and does not adequately recognise the cultural wealth our diverse cohorts arrive with (O'Shea, 2016).

In response to this situation, I have worked collaboratively with students in the design and development of programs that seek to support learners in their transition into university and during their initial engagement with the institution (O'Shea, 2012; O'Shea \& Vincent, 2011). Like Matthews (2016), I regard such collaborations as a means to bring together diverse perspectives in the HE environment, recognising that "this diversity forms the foundation of fruitful partnerships in acknowledging that we bring different but equally valuable perspectives to the joint enterprise of education" (Matthews, 2016, p. 3).

My most recent activities include a student mentoring program that is grounded within the students-as-partners framework (O'Shea, Bennett, \& Delahunty, 2017). While we know that peer mentoring programs are beneficial to students, these are often designed and developed by staff for student rather than in partnership with them. Beginning with the formation of a student-staff committee that unpacked the concept of mentoring, our particular approach sought to design a program from the ground up, recognising that it is students who are best placed to "expose the implicit or hidden curriculum of university" as they are "already on that journey" (O'Shea, Bennett, \& Delahunty, 2017, p. 114). Such genuine collaborations offer the potential for learning for all participants as both staff and learners navigate alternative understandings about the inner workings of the institutions, as the following comments indicate:

To be able to sit at a table as an equal with our undergrad students for me, that was an uplifting experience... I believe it's worthwhile.

(Staff Committee Member, Students as Partners in Mentoring (SaPiM) Program)

This experience enabled me to collaborate with other educators and engage professionally with colleagues. I learnt that when working together for the same goal 
ideas and action flow quite easily and goals can be accomplished. I also learnt more about the University... and the range of assistances on offer. I have grown ... through this experience.

(Student Committee Member, SaPiM Program)

Mann (2001) argues that the structures and practices of university exacerbate alienation in students, and the ongoing emphasis on "utilitarianism" and "performativity" (p. 8) ultimately reduces learning to functions or competencies rather than recognising individual meaning systems. Arguably the students-as-partners framing refocuses learning to value actual lived experience and also challenges traditional institutional roles such as student and academic, positions that both have power implications and also reduce individuals to a category or "type" (Mann, 2001, p. 10). Matthews (2017) expands on the isolating nature of HE, to propose how partnership frameworks offer a "counter-narrative to current neoliberal agendas that translate into client-commodity-customer discourses of students" (p. 1). While offering great opportunities, there are also a number of considerations before implementing students-aspartners practices or approaches within the equity field.

\section{RECOMMENDATIONS AND CAUTIONARY CONSIDERATIONS}

The following recommendations and cautions are derived from my own experiences of collaborating with students in the design, development, and implementation of programs that seek to support equity students during their transition into university and throughout their academic journey. This list offers some insights that may assist others as they undertake similar endeavours:

- The relational aspects of students-as-partners and the need for student and staff ownership of this process should characterise all student-as-partners activities, but this concept of doing with rather than doing to is particularly significant to activities within the equity and outreach field. This relationship should be collaborative, with power held equally by all parties and outputs and with activities characterised by immediacy and authenticity.

- To further ensure such authenticity, all partner activities in the equity field should utilise multiple channels of contact for student partners, recognising that some cohorts do not regularly engage in on-campus groups or associations. There is also a need to explicitly invite students with diverse life experiences to participate in partnership programs; these individuals include those who have taken a non-linear pathway into and through university, many of whom will have had disrupted university journeys. Such diverse routes provide a wealth of knowledge and experience that can effectively inform programs and support offered to diverse learners.

- With universities, there is a need to adopt a range of less formal ways to engage students in these partnerships, such as not requiring resumes or participation in an interview, as well as building in strategies that avoid targeting only high achieving students. 


\section{CONCLUSIONS}

While the number of students attending university grows, we must question whether we have achieved a more equitable tertiary landscape. Across a number of countries, the stratification of certain learners relates to factors such as university choice (Reay, 2017), learner pathways (Lim, 2015), and retention rates (Higher Education Standards Panel, 2018). Within equity and outreach, there remains a focus on raising aspirations among students when perhaps, as Cummings et al. (2012) argue, the focus should rather be about "keeping aspirations on track" (p. 1). Students-as-partners practices offer the possibility of accomplishing this in a meaningful and productive way. This perception of aspirations is very different to the static assumption that aspirations are low and so need to be raised. Instead, these need to be regarded as fluid and dynamic depending on the horizons and opportunities of individuals and, more importantly, on learners' access to "peers, family and educators" (Cummings et al., 2012, p. 72). The fundamental strength of a student partnership approach is that it not only creates trust-filled partnerships between staff and students but also engenders what Cook-Sather (2016) refers to as "brave spaces" where multiple aspirations can be considered and supported. As such, forging these types of collaborative ventures within the equity and outreach space offers potential to envision and create a university for all rather than for just some.

NOTE ON CONTRIBUTOR

Dr Sarah O'Shea is an Associate Professor in Adult, Vocational and Higher Education in the School of Education at the University of Wollongong, Australia.

\section{REFERENCES}

Cliffe, A., Cook-Sather, A., Healey, M., Healey, R., Marquis, E., Matthews, K. E., MercerMapstone, L., Ntem, A., Puri, V., \& Woolmer, C. (2017). Launching a journal about and through students as partners. International Journal for Students as Partners, 1(1).

Cook-Sather, A. (2016). Creating brave spaces within and through student-faculty pedagogical partnerships. Teaching and Learning Together in Higher Education (18). Retrieved from https://repository.brynmawr.edu/tlthe/vol1/iss18/1

Cook-Sather, A., Bovill, C., \& Felten, P. (2014). Engaging students as partners in learning and teaching: A guide for faculty. San Francisco, CA: Jossey-Bass.

Cummings, C., Laing, K., Law, J., McLaughlin, J., Papps, I., Todd, L., \& Woolner, P. (2012). Can changing aspirations and attitudes impact on educational attainment? A review of interventions. York: Joseph Rowntree Foundation.

Higher Education Standards Panel. (2018). Final report: Improving retention, completion and success in higher education. Canberra: Department of Education.

Lim, P. (2015). Do individual background characteristics influence tertiary completion rates? A 2014 student equity in higher education research grants project. National Centre for Student Equity in Higher Education. Perth: Curtin University.

Mann, S. (2001). Alternative perspectives on the student experience: Alienation and engagement. Studies in Higher Education, 26(1), 7-19. 
Marginson, S. (2016). The worldwide trend to high participation in higher education: Dynamics of social stratification in inclusive systems. Higher Education, 72, 413-434.

Matthews, K. E. (2016). Students as partners as the future of student engagement. Student Engagement in Higher Education Journal, 1(1), 1-5.

Matthews, K. E. (2017). Five propositions for genuine students as partners practice. International Journal for Students as Partners, 1(2), 1-9.

Matthews, K. E., Cook-Sather, A., \& Healey, M. (2018). Connecting learning, teaching and research through student-staff partnerships. In V. Tong, A. Standen \& M. Sotiriou (Eds.), Shaping higher education with students: Ways to connect research and training. London: UCL Press.

Matthews, K. E., Dwyer, A., Hine, L., \& Turner, J. (2018). Conceptions of students as partners. Higher Education, Online First, 1-15.

O'Shea, S. (2012). UStart: A peer designed and led orientation activity. E-Source for College Transitions, 9(2), 4-6.

O'Shea, S. (2016). First-in-family learners and higher education: Negotiating the 'silences' of university transition and participation. HERDSA Review of Higher Education (Vol 3), 5-23.

O'Shea, S. (2016). Avoiding the manufacture of "sameness": First-in-family students, cultural capital and the higher education environment. Higher Education, 72(1), 59-78.

O'Shea, S., Bennett, S. \& Delahunty, J. (2017). Engaging 'students as partners' in the design and development of a peer-mentoring program. Student Success, 8(2), 113-116.

O'Shea, S. \& Delahunty, J. (2018). Getting through the day and still having a smile on my face! How do students define success in the university learning environment? Higher Education Research and Development. 37(5), 1062-1075.

O'Shea, S. \& Vincent, M. (2011) Uni-Start: A peer-led orientation activity designed for the early and timely engagement of commencing university students. The Journal of Continuing Higher Education, 59(3), 152-161.

Reay, D. (2017). Miseducation: Inequality, education and the working classes. Bristol: Policy Press. 